\title{
ANALISIS DAN PENGUJIAN KINERJA TURBIN ANGIN SAVONIUS 4 SUDU
}

\author{
J. Victor Tuapetel ${ }^{1, a)}$, Ikbal Arif Triprayoga ${ }^{2, b)}$, Putu M. Santika ${ }^{3, c)}$ \\ 1,2,3 Program Studi Teknik Mesin ITI, \\ Jl. Raya Puspiptek Serpong, Tangerang Selatan-Banten, Indonesia, 15320

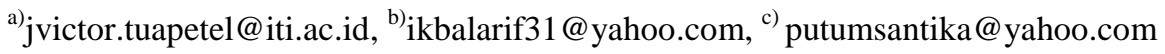

\begin{abstract}
Abstrak
Pada tahun 2016, penggunaan batubara masih mendominasi sebagai bahan bakar pembangkit, yaitu $62 \%$ atau sekitar 75 juta ton (315 juta Setara Barel Minyak atau SBM). Untuk bahan bakar fosil lain, seperti gas dan minyak, masing-masing adalah 17\% (87 juta SBM) dan 5\% (25 juta SBM). Adapun sisanya sebesar 16\% (77 juta SBM) diisi oleh bakar yang berasal dari energi baru terbarukan, seperti panas bumi, air, matahari, serta biomassa. Penelitian ini menganalisis kinerja turbin angin tipe savonius 4 sudu dengan posisi 2 tingkat yang dilakukan di Pantai Tanjung Pasir, Kecamatan Teluknaga, Kabupaten Tangerang. Hasil yang diperoleh yaitu kecepatan angin tertinggi terjadi pada 14.45-14.50 WIB sebesar 5,2 m/det. Daya generator dari kecepatan angin tersebut sebesar 10,5 watt. Kecepatan angin terendah terjadi pada pukul 13.45-13.50 sebesar 3,9 m/det dan daya generator yang dihasilkan sebesar 4,18 watt. Koefisien power tertinggi yaitu sebesar 0,027 dan terendah sebesar 0,019.
\end{abstract}

Kata Kunci : energi angin, daya generator, turbin angin savonius

\begin{abstract}
In 2016, the use of coal was still dominate as fuel generation, which was 62\% or around 75 million tons (315 million Barrel of Oil Equivalent or BOE). Another fossil fuel, such as gas and oil, each of them was 17\% (87 million BOE) and 5\% (25 million BOE). And the remain 16\% (77 million BOE) was fuel generation from renewable energy sources, such as geothermal, water, solar, and biomass. This study aims to analyze the blade savonius wind turbine with 2 levels section at Tanjung Pasir Beach, Teluknaga, Tangerang. The obtained result are the highest wind speed occurs at 14.45-14.50 WIB at 5,2 m/s and the power generator of wind speed is 10,5 watt. The lowest wind speed occurs at 13.45-13.50 WIB at 3,9 m/s and the power generator is 4,18 watt. The highest coefficient of power is 0,027 and the lowest $\mathrm{0} 0,019$.
\end{abstract}

Keywords: wind energy, generator power, savonius wind turbine.

\section{PENDAHULUAN}

\section{A.Latar Belakang}

Kebutuhan energi di Indonesia dari tahun ke tahun semakin meningkat. Hal ini terjadi dikarenakan, bertambahnya jumlah penduduk, pertumbuhan ekonomi dan pemakaian energi yang terus bertambah. Dari data komsumsi energi di Indonesia hingga 2050 seperti pada Gambar 1, laju pertumbuhan kebutuhan energi final sebesar 5,3\% per tahun. Untuk itu, kebutuhan energi meningkat dari 795 juta SBM pada tahun 2016 menjadi 4.569 juta pada tahun 2050. Pada tahun 2050, pangsa kebutuhan energi final terbesar adalah bahan bakar minyak (BBM) yakni sebesar 40,1\% diikuti oleh listrik $(21,3 \%)$, gas $(17,7 \%)$, batubara $(11,0 \%)$, dan sisanya LPG, bahan bakar nabati (BBN) dan biomassa masing-masing di bawah 4\%. [1]

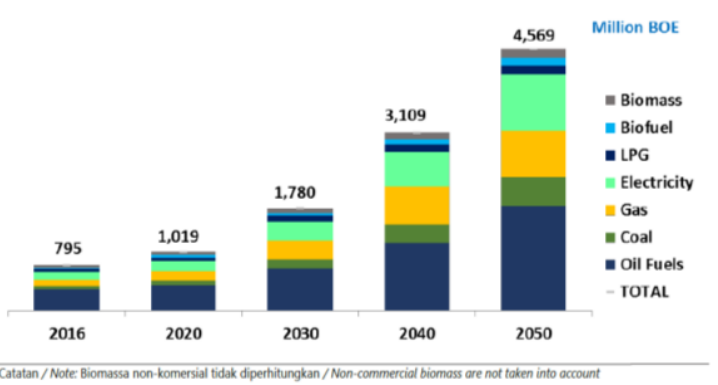

Gambar 1. Kebutuhan Energi Final Berdasar Jenis [1]

Pada tahun 2016, penggunaan batubara masih mendominasi sebagai bahan bakar pembangkit, yaitu $62 \%$ atau sekitar 75 juta ton (315 juta SBM). Untuk bahan bakar fosil lain, seperti gas dan minyak, masing-masing adalah 17\% (87 juta SBM) dan 5\% (25 juta SBM). Adapun sisanya sebesar 16\% (77 juta SBM) diisi oleh bakar yang berasal dari energi baru terbarukan, seperti panas bumi, air, matahari, serta biomassa. 
Energi baru dan terbarukan (EBT) merupakan pengganti dari energi yang berbahan konvensional. Energi terbarukan adalah energi yang tidak dikhawatirkan jumlahnya karena energi ini berasal dari alam yang berkelanjutan. Energi angin merupakan salah satu EBT yang dapat dimanfaatkan sebegai sumber energi dengan menggunakan kincir angin atau turbin angin. Energi mekanik yang dihasilkan oleh turbin angin dapat dimanfaatkan secara langsung atau dikonversi menjadi energi listrik.

Turbin angin savonius merupakan turbin yang cocok digunakan di Indonesia karena kecepatan anginnya rendah. Keuntungan lainnya adalah desain dan konstruksi turbin angin savonius yang sederhana dan dapat menerima angin dari segala arah

\section{B. State Of The Art}

Simulasi CFD (Cimulating Fluid Dynamics) merupakan metode perhitungan dengan metode komputasi untuk melakukan perhitungan pada tiaptiap elemen pembaginya. Hasil dari simulasi tersebut adalah kecepatan angin $5 \mathrm{~m} / \mathrm{det}$ diperoleh bahwa penambahan plat pengarah bekerja efektif pada posisi $30^{\circ}$ dan $105^{\circ}$ dan bekerja maksimum pada posisi sudu $45^{\circ}$. Kincir dengan tambahan plat pengarah pada posisi sudu $45^{\circ}$ dan $90^{\circ}$ memiliki torsi statis yang lebih tinggi dibanding dengan torsi statis kincir standar. Kenaikan torsi statis sebesar $30 \%$ pada kincir model 2 sebagai akibat kenaikan kecepatan angin pada sisi cembung baik pada sudu dorong maupun sudu balik dibandingkan dengan kincir Savionius tanpa pengarah [2].

Kecepatan angin maksimum terjadi antara pukul 14.00 s.d 18.00 WIB setiap hari. Nilai kecepatan angin minimum dan maksimum selama satu minggu pengukuran adalah 0,26 $\mathrm{m} /$.det dan $4,9 \mathrm{~m} / \mathrm{det}$. Sedangkan kecepatan rata-rata angin adalah 1,44 $\mathrm{m} /$ det. Untuk rata-rata daya efektif dari yang dihasilkan oleh suatu turbin angin antara 0,38 s.d 1,32 $\mathrm{W}$ dengan diameter sapuan 1 meter atau ratarata $0,74 \mathrm{~W}[3]$.

Di antara semua jenis turbin yang disimulasikan, peningkatan daya terjadi pada turbin jenis VAWTDB (Vertical Axis Wind Turbine Deformable Blade) dengan 3 sudu dan koesfisien daya maksimum meningkat sekitar $14,56 \%$ lebih tinggi dari pada VAWT (Vertical Axis Wind Turbine) konvensional. Sedangkan koefisien daya maksimum dari turbin jenis VAWTDB 4 sudu dan 2 sudu terjadi peningkatan masing-masing yaitu $8,07 \%$ dan $7,51 \%$ [4].

Kincir angin dengan tiga sudu mampu mengekstrasi daya angin menjadi daya generator (output) rata-rata $30 \%$. Untuk daya angin tertinggi pada pengujian $\mathrm{v}=4,2 \mathrm{~m} /$ det yaitu 2,99 watt, daya output generator 0,77 watt. Dapat diartikan bahwa kincir angin hanya mampu mengekstraksi daya angin menjadi daya generator sebesar 26\%. Daya terendah pada pengujian $\mathrm{v}=1,6 \mathrm{~m} /$ det yaitu 0,17 watt daya ouput generator 0,02 watt. Dapat diartikan bahwa kincir angin hanya mampu mengekstraksi daya angin menjadi daya generator sebesar $13 \%$ [5].

C. Tujuan Penelitian

Tujuan dari penelitian ini untuk mengetahui kinerja/performance turbin angin tipe savonius 4 sudu terhadap daya yang dihasilkan.

D. Metodologi Penulisan

Metodelogi penulisan adalah sebagai berikut :

- Survey lokasi yang mempunyai kecepatan angin sesuai kebutuhan.

- Studi literatur yakni berupa studi kepustakaan, kajian dari buku dan tulisan-tulisan yang terkait dengan penelitian.

- Metode diskusi yakni berupa diskusi antara mahasiswa dengan dosen pembimbing mengenai kincir angin.

\section{LANDASAN TEORI}

\section{A. Kincir Angin}

Kincir angin adalah sebuah alat yang digerakkan oleh tenaga angin sehingga menghasilkan energi mekanik atau gerak. Kincir angin dulunya banyak ditemukan di negara-negara Eropa khususnya Belanda dan Denmark yang pada waktu itu banyak digunakan untuk irigasi, menumbuk hasil pertanian dan penggilingan gandum.

Pada saat ini kincir angin telah dimanfaatkan sebagai pembangkit listrik. Kincir angin yang digunakan untuk menghasilkan sebuah energi listrik disebut dengan turbin angin (wind turbine). Turbin angin mampu mengubah energi angin menjadi energi mekanik dengan memanfaatkan putaran kincir untuk memutar generator sehingga akan dihasilkan energi listrik.

Berdasarkan posisi poros kincir angin dibedakan menjadi dua kelompok utama, yaitu kincir angin poros horizontal dan kincir angin poros vertikal. Dalam penelitian ini akan membahas mengenai kincir angin poros vertikal.

\section{$>$ Kincir Angin Poros Horizontal}

Kincir angin poros horizontal atau Horizontol Axis Wind Turbine (HAWT) memiliki poros rotor utama dan generator listrik di puncak menara. Kincir berukuran kecil diarahkan oleh sebuah baling-baling angin yang sederhana, sedangkan kincir berkuranan besar pada umumnya menggunakan sebuah sensor 
angin yang digabungkan ke sebuah servo motor. Sebagian besar memiliki sebuah gearbox yang mengubah perputaran kincir yang pelan menjadi lebih cepat berputar. Bentuk dari kincir angin poros horizontal dapat dilihat pada Gambar 2.

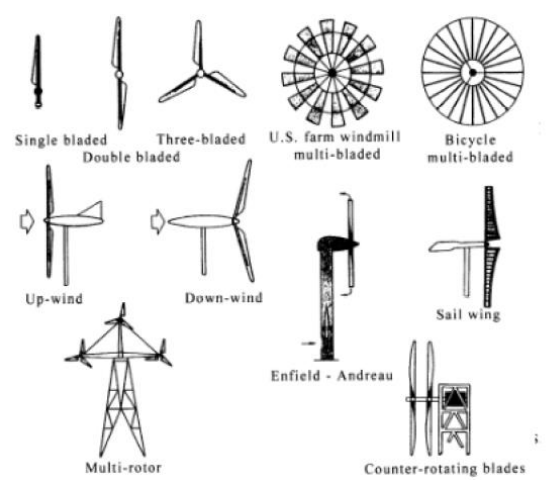

Gambar 2. Bentuk-Bentuk Kincir Angin Poros Horizontal [6]

\section{$>$ Kincir Angin Poros Vertikal}

Kincir angin poros vertikal atau Vertical Axis Wind Turbine (VAWT) merupakan turbin angin sumbu tegak yang gerakan poros dan rotor sejajar dengan arah angin, sehingga rotor dapat berputar pada semua arah angin. VAWT juga mempunyai beberapa kelebihan dan kekurangan. Bentuk dari kincir angin poros vertikal dapat dilihat pada Gambar 3. Terdapat tiga model rotor pada turbin angin jenis ini, yaitu: Savonius, Darrieus, dan H rotor. Turbin Savonius memanfaatkan gaya drag sedangkan Darrieus dan H rotor memanfaatkan gaya lift [2].
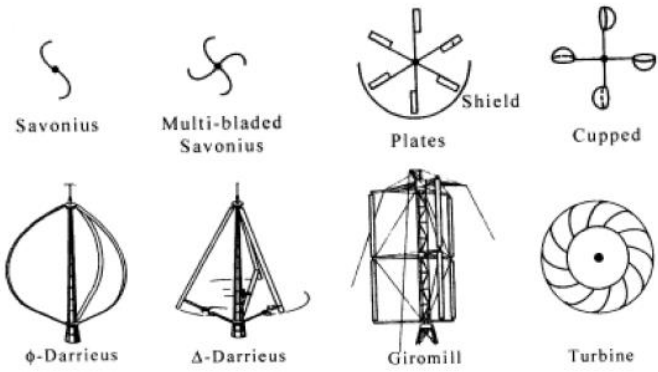

Gambar 3. Bentuk-Bentuk Kincir Angin Poros Vertikal

Kelebihan kincir angin sumbu vertikal adalah :

1. Perawatan kincir angin ini cukup mudah karena letaknya yang dekat dengan permukaan tanah.

2. Memiliki kecepatan pengawalan angin yang rendah dibandingkan dengan sumbu horizontal.

3. Kincir angin ini dapat menerima hembusan angin dari segala arah.

4. Tidak memerlukan menara yang tinggi sehingga lebih murah dan kuat
Kelemahan kincir angin sumbu vertikal adalah :

1. Memiliki kecepatan putaran yang rendah, karena letaknya dekat dengan tanah.

2. Pada umumnya dipasang dekat dengan permukaan tanah maka kualitas angin yang diterima kurang baik sehingga kincir angin mudah rusak.

\section{$\checkmark$ Kincir Angin Vertikal Tipe Savonius}

Kincir angin savonius merupakan alat untuk mengubah energi kecepatan angin menjadi energi gerak dengan poros vertikal yang mudah dibuat, dapat menerima angin dari segala arah dan dapat bekerja pada kecepatan angin yang rendah. Kincir angin savonius pada umumnya didesain silinder terbelah yang digeser sehingga membentuk seperti hurus $\mathrm{S}$ seperti ditunjukkan pada Gambar 4 dengan $D$ : diameter kincir, $D_{0}$ : diameter end plate dan $e$ : jarak overlap.

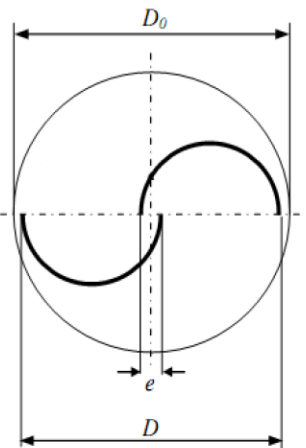

Gambar 4 . Skema Kincir Angin Savonius

\section{$\checkmark \quad$ Kincir Angin Vertikal Tipe Darrieus}

Kincir angin tipe ini ditemukan oleh seorang insinyur perancis bernama George Jeans Maria Darrieus yang dipatenkan pada tahun 1931. Ia memiliki 2 bentuk turbin diantaranya adalah eggbeater/curved bladed dan straight-balded seperti ditunjukkan pada Gambar 5. Kincir angin tipe darrieus mempunyai bilah sudu yang disusun dalam posisi simetri dengan sudu bilah yang diatur relatif terhadap poros.

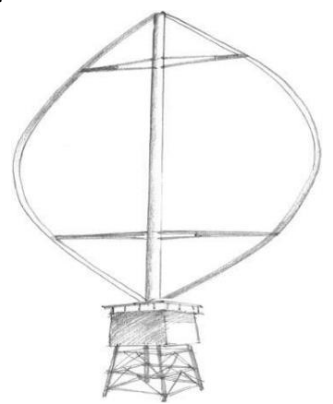

Gambar 5. Kincir Angin Tipe Darrieus 


\section{B. Rumus Perhitungan}

Berikut ini adalah rumus-rumus yang digunakan untuk melakukan perhitungan dan analisis kerja kincir angin yang diteliti.

\section{Daya Angin}

Daya angin $\left(P_{i n}\right)$ adalah daya yang dihasilkan oleh sudu kincir angin yang diakibatkan oleh hembusan angin. Daya angin dapat dirumuskan sebagai berikut:

Dimana :

$$
P_{\text {in }}=\frac{1}{2} \rho \cdot A \cdot v^{3}
$$

$$
\begin{array}{ll}
\rho & : \text { massa jenis udara }\left(\mathrm{kg} / \mathrm{m}^{3}\right) \\
\mathrm{A} & : \text { luas penampang sudu }\left(\mathrm{m}^{2}\right) \\
\mathrm{V} & : \text { kecepatan angin }(\mathrm{m} / \mathrm{s})
\end{array}
$$

\section{Torsi (T)}

Torsi adalah hasil kali dari gaya pembebanan $(\mathrm{F})$ dengan panjang lengan torsi (1). perhitungan torsi dapat dirumuskan sebagai berikut:

$$
T=F \cdot \ell
$$

\section{Daya Kincir Angin}

Daya yang dihasilkan kincir $\left(P_{\text {out }}\right)$ adalah daya dihasilkan kincir akibat adanya angin yang melintasi sudu/bilah kincir. Sehingga daya kincir yang dihasilkan oleh gerakkan melingkar kincir dapat dirumuskan

$$
P_{\text {out }}=T . \omega
$$

Dimana :

$$
\begin{array}{ll}
\mathrm{T} & : \text { Torsi }(\mathrm{N} . \mathrm{m}) \\
\omega & : \text { kecepatan sudut }(\mathrm{rad} / \mathrm{s})
\end{array}
$$

\section{Tip Speed Ratio (tsr)}

Tip speed ratio adalah perbandingan antara kecepatan linear lingkaran terluar kincir dengan kecepatan angin. Perhitungan nilai tip speed ratio dapat dirumuskan sebagai berikut:

Dimana:

$$
t s r=\frac{\omega \cdot r}{v}
$$

r $\quad$ : jari-jari kincir (m)

\section{Koefisien Daya $\left(C_{p}\right)$}

Koefisien daya adalah perbandingan antara daya yang dihasilkan oleh kincir angin dengan daya yang disediakan oleh angin. Perhitungan nilai koefisien daya dapat dirumuskan sebagai berikut:

Dimana:

$$
C_{p}=\frac{P_{\text {out }}}{P_{\text {in }}} .100 \%
$$

$\begin{array}{ll}P_{\text {out }} & \begin{array}{l}\text { : daya yang dihasilkan oleh kincir angin } \\ \text { (Watt) }\end{array} \\ P_{\text {in }} & \text { : daya yang disediakan oleh angin (Watt) }\end{array}$

Menurut ilmuwan asal Jerman, Albert Betz. Efisiensi atau koefisien daya maksimal sebuah kincir angin adalah sebesar $59 \%$. Teori tersebut kemudian dinamakan dengan Betz limit yang grafiknya dapat dilihat pada Gambar 6.

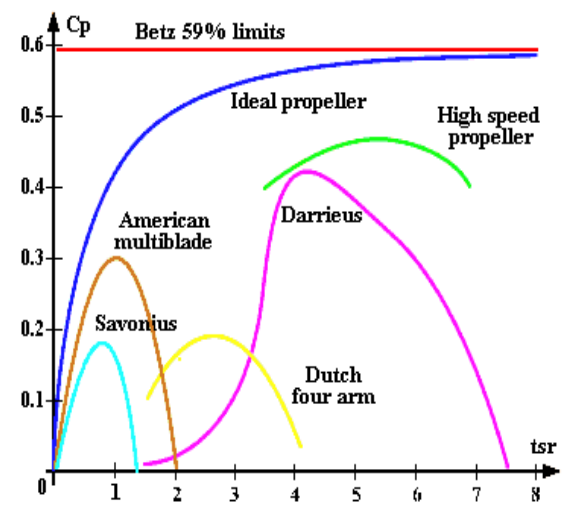

Gambar 6. Grafik Hubungan Antara Koefisien Daya Dengan Tip Speed Ratio Dari Berbagai Jenis Kincir Angin.

\section{METODOLOGI PENELITIAN}

A. Diagram Alir

Diagram alir penelitian ditunjukan pada Gambar 7.
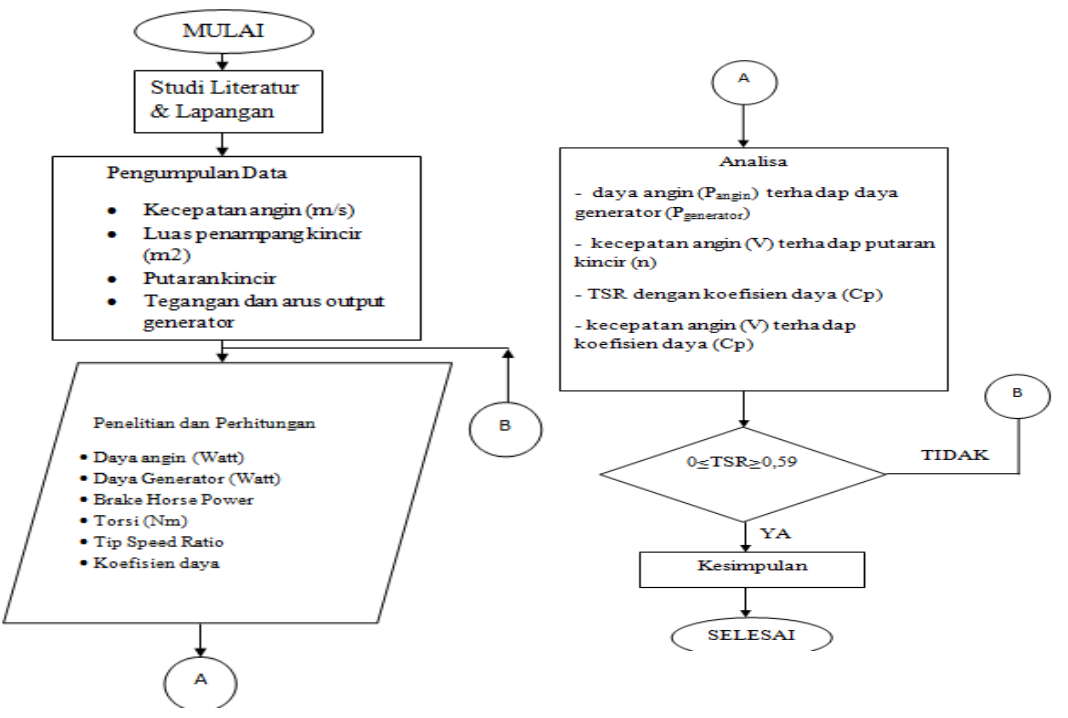

Gambar 7. Diagram Alir Analisis dan Pengujian Kinerja Turbin Angin Tipe Savonius 4 Sudu 


\section{B. Penjelasan Diagram Penelitian}

Tahap pertama yang harus dilakukan sebelum memulai penelitian adalah mencari literatur yang berkaitan dengan performa turbin angin tipe savonius 4 sudu dan melakukan studi lapangan untuk menentukan lokasi dengan keadaan angin yang tepat.

Tahap kedua adalah mencari data-data tentang parameter yang dibutuhkan untuk membantu penelitian serta perhitungan performan turbin angin.

Tahap Ketiga adalah membuat perhitungan tentang hal-hal yang berkaitan dengan performan turbin angin yaitu, daya angin, daya generator, Brake Horse Power (BHP), torsi, Tip Speed Ratio (TSR) dan koefisien daya.

Tahap keempat adalah menganalisa dari hasil perhitungan yang telah didapat dari tahap sebelumnya. Melihat pengaruh daya angin $\left(\mathrm{P}_{\text {angin }}\right)$ terhadap daya generator $\left(\mathrm{P}_{\text {generator }}\right)$. Selanjutnya adalah melihat pengaruh kecepatan angin (V) terhadap putaran kincir (n). berikutnya adalah hubungan antara TSR dengan koefisien daya (Cp). Terakhir adalah pengaruh kecepatan angin (V) terhadap koefisien daya (Cp).

Tahap kelima adalah kesimpulan, penulis menyimpulkan hasil dari penelitian dan perhitungan Serta dapat menerangkan faktor apa saja yang mempengaruhi kinerja atau performa turbin angin savonius 4 sudu sehingga penulis dapat benar-benar mengetahui kondisi turbin angin pada saat dilakukannya penelitian.

\section{HASIL DAN PEMBAHASAN}

Data yang diambil berupa nilai kecepatan angin dan suhu yang diukur dengan menggunakan anemometer. Selanjutnya adalah mengetahui nilai putaran pada poros motor listrik yang diukur menggunakan tachometer. Lalu yang terakhir adalah nilai tegangan dan arus yang diukur dengan menggunakan multimeter digital. Pengambilan data dilakukan di Pantai Tanjung Pasir, Kecamatan Teluknaga, Kabupaten Tangerang pada hari Sabtu, 20 Juli 2019 pukul 14.30 -15.50 WIB dengan melihat nilai tertinggi dari dari pengukuran pada range waktu 5 menit dan diambil 10 .

\section{A. Daya Angin $\left(P_{\text {angin }}\right)$ dan Daya Generator $\left(P_{\text {generator }}\right)$ Terhadap Waktu}

Perbandingan antara waktu terhadap daya angin dan daya generator merupakan keluaran dari kincir angin yang memprlihatkan daya generator meningkat seiring dengan meningkatnya daya angin. Untuk daya generator tertinggi sebesar 10,5 watt terjadi pada pukul 14.45-14.50 dengan daya angin sebesar 541,01 watt. Daya generator terendah terjadi pada pukul 13.45-13.50 dengan besar daya 4,18 watt, daya input/daya angin yang terjadi sebesar 228,24 watt. Berikut adalah grafik antara waktu terhadap daya generator pada Gambar 8 dan waktu terhadap daya angin seperti pada Gambar 9.

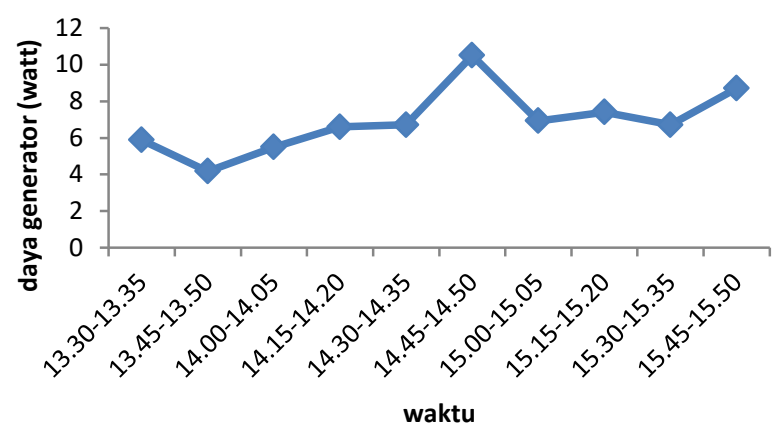

Gambar 8. Grafik Waktu Terhadap Daya Generator

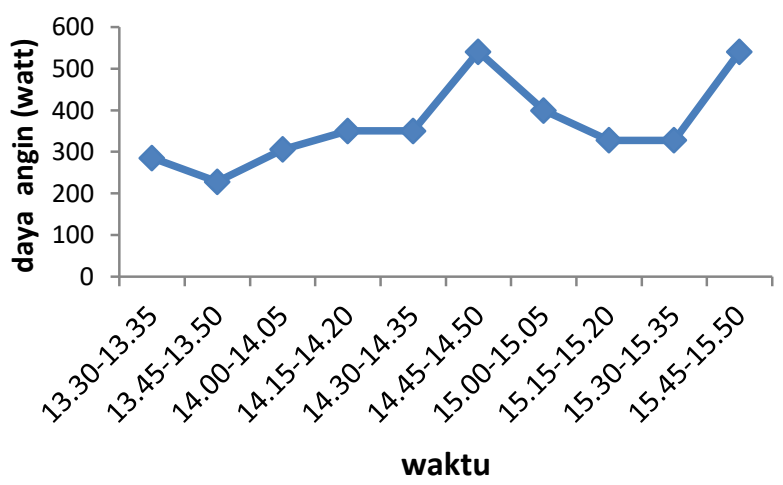

Gambar 9. Grafik Waktu Terhadap Daya Angin

\section{B. Waktu Terhadap Kecepatan Angin (V) Dan Putaran Kincir (N)}

Diketahui bahwa seiring dengan bertambahnya kecepatan angin maka putaran pada poros motor listrik semakin bertambah juga begitupun sebaliknya. Kecepatan angin terbesar terjadi pada pukul 14.45$14.50 \& 15.45-15.50$ WIB dengan besar kecepatan $5,2 \mathrm{~m} / \mathrm{s}$, namun putaran yang dihasilkan berbeda dikarenakan kecepatan angin yang tidak konstan. Putaran dari sudu menuju poros generator memerlukan waktu beberapa detik, sehingga pada pukul 15.45-15.50 WIB saat angin mencapai kecepatan tertinggi seperti pada Gambar 10 yaitu 5,2 $\mathrm{m} / \mathrm{s}$ lalu mengalami penurunan kecepatan yang cukup drastis sehingga daya generator yang dihasilkan mengalami perbedaan. Untuk putaran poros terendah dapat dilihat pada Gambar 11 terjadi pada pukul 13.45-13.50 dan menghasilkan putaran sebesar 206,7 rpm. 


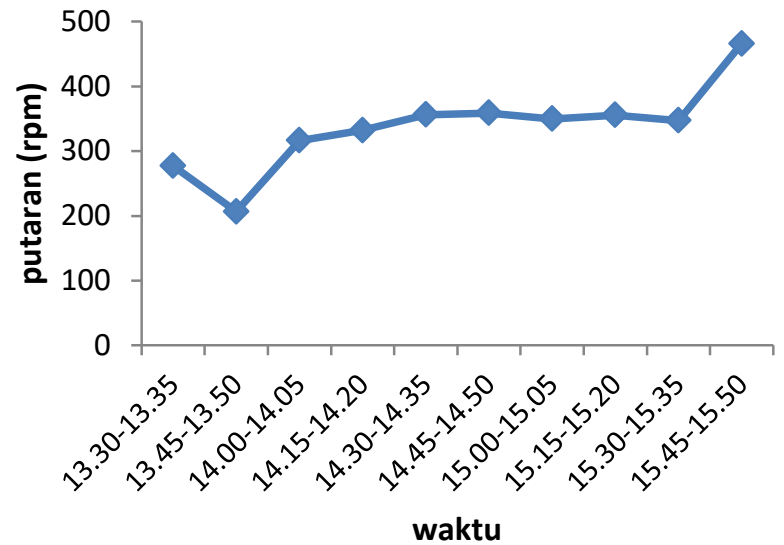

Gambar 10. Grafik Waktu Terhadap Putaran

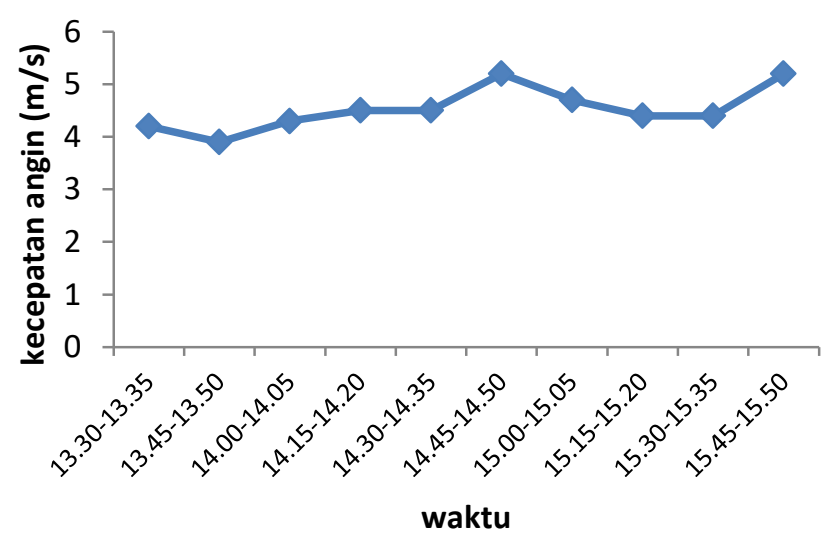

Gambar 11. Grafik antara waktu terhadap kecepatan angin

\section{TSR Dengan Koefisien Daya (Cp)}

Grafik perbandingan tip speed ratio dengan koefisien power pada Gambar 12 menunjukan bahwa turbin angin savonius dengan 4 sudu memiliki koefisien power tertinggi sebesar 0,027 dengan besar tip speed ratio sebesar 0,84 . Untuk koefisien power terendah terjadi pada saat tip speed ratio sebesar 0,019 sebesar 0,71 .

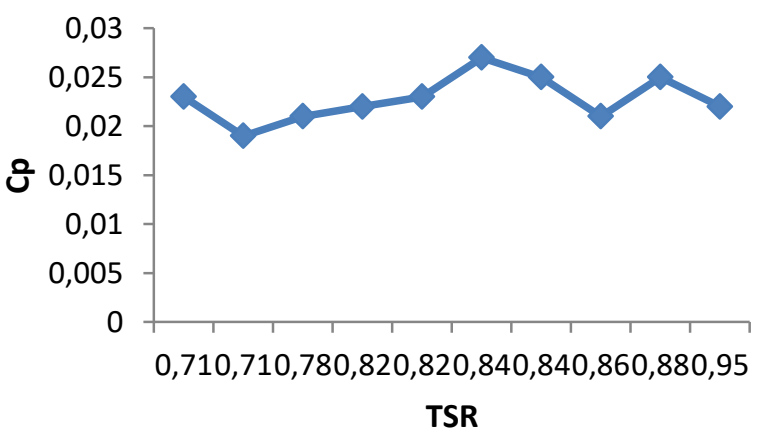

Gambar 12. Grafik Antara TSR Terhadap Koefisien Daya

\section{Kecepatan Angin (v) Terhadap Koefisien Daya ( $\mathrm{Cp})$}

Pada Gambar 13 menunjukan bahwa grafik hubungan antara kecepatan angin dengan koefisien power menunjukan bahwa turbin angin savonius 4 sudu memiliki koefisien power terbesar terjadi pada saat kecepatan angin 4,4 m/s dengan besar 0,027. Nilai koefisien terendah sebesar 0,019 dengan kecepatan angin $5,2 \mathrm{~m} / \mathrm{s}$.

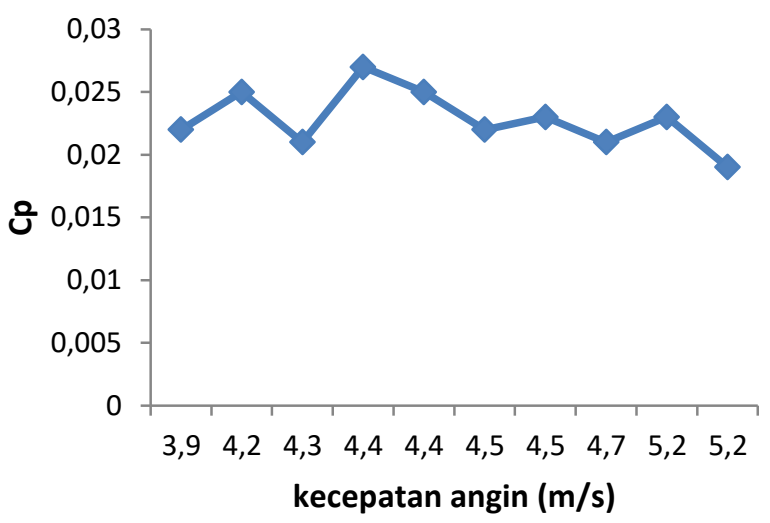

Gambar 13. Grafik Antara Kecepatan Angin Terhadap Koefisien Power (Cp)

\section{E. Waktu terhadap tegangan (V) dan arus (I)}

Grafik hubungan antara waktu terhadap tegangan dan arus seperti ditunjukkan pada Gambar 14 bahwa tegangan yang terjadi berbanding lurus dengan arus listrik. Tegangan listrik tertinggi terjadi pada pukul 14.45-14.50 sebesar 7 volt dengan arus sebesar 1,5 ampere. Untuk tegangan terendah sebesar 3,8 volt dengan arus sebesar 1,1 ampere terjadi pada pukul 13.45-13.50.

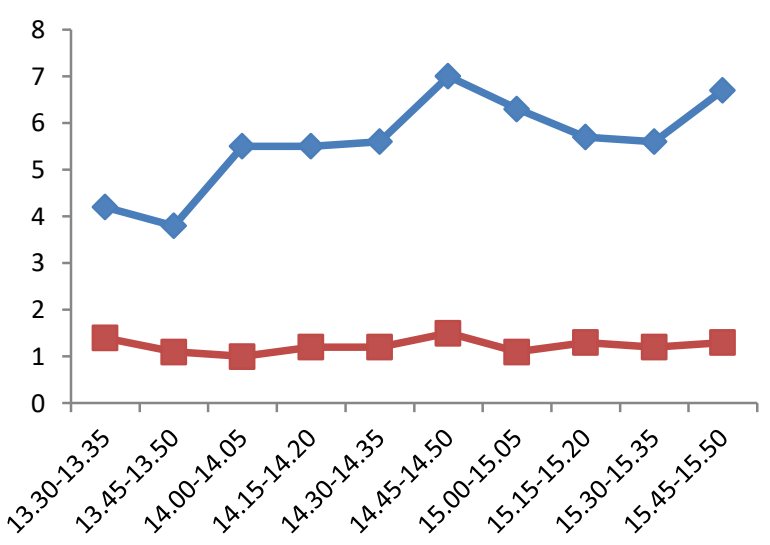

Gambar 14. Grafik Waktu Terhadap Tegangan (V) dan Arus (I) 


\section{KESIMPULAN}

Berdasarkan pengujian dan analisis kinerja/performance turbin angin savonius 4 sudu yang dilakukan di pantai Tanjung Pasir, Kecamatan Teluknaga, Kabupaten Tangerang pada tanggal 20 Juli 2019 pukul 14.30 -15.50 WIB dapat disimpulkan bahwa :

1. Kecepatan angin maksimum di Pantai Tanjung Pasir terjadi pada pukul 14.30-14.35 \& 15.4515.50 WIB dengan besar kecepatan yaitu 5,2 $\mathrm{m} / \mathrm{s}$. kecepatan angin minimum terjadi pada pukul 13.45-13.50 dengan kecepatan 3,9 m/s

2. Putaran pada poros motor berbanding lurus dengan kecepatan angin, begitu pula sebaliknya. Pada putaran poros tertinggi yaitu $466 \mathrm{rpm}$ terjadi pada kecepatan angin $5,2 \mathrm{~m} / \mathrm{s}$. Untuk putaran terendah yaitu 206,7 rpm pada kecepatan angin $3,9 \mathrm{~m} / \mathrm{s}$.

3. Daya generator yang dihasilkan semakin besar seiring dengan bertambahnya kecepatan angin. Angin pada kecepatan tertinggi yaitu $5,2 \mathrm{~m} / \mathrm{s}$ menghasilkan daya generator sebesar 10,5 watt. Pada kecepatan angin terendah yaitu $3,9 \mathrm{~m} / \mathrm{s}$ menghasilkan daya generator sebesar $4,18 \mathrm{~m} / \mathrm{s}$

4. Koefisien power tertinggi sebesar 0,027 dengan besar tip speed ratio sebesar 0,84. Untuk koefisien power terendah terjadi pada saat tip speed ratio sebesar 0,019 sebesar 0,71 .

\section{REFERENSI}

[1] BPPT. (2018). Outlook energi indonesia 2018. Retrieved April 2, 2019, from http://www.bppt.go.id.

[2] Sugiharto, B. dkk. (2015). Simulasi peningkatan kinerja kincir angin savonius dengan empat plat pengarah. SEMINAR NASIONAL TEKNOLOGI (SENATEK), 53-58.

[3] Abdullah, I. dkk. (2016). Kajian potensi energi angin di daerah kawasan pesisir pantai serdang bedagai untuk menghasilkan energi listrik. Jurnal Ilmiah Mekanik Teknik Mesin ITM, 2(1), 31-38.

[4] Wang, Y., Sun, X., Dong, X., Zhu, B., Huang, D., \& Zheng, Z. (2016). Numerical investigation on aerodynamic performance of a novel vertical axis wind turbine with adaptive blades. Energy Conversion and Management, 108, 275-286.

[5] Petriadi, P. dkk. (2018). Analisis performance kincir angin sumbu vertikal tiga sudut dengan kelengkungan $90^{\circ}$. POLITEKNOLOGI, 17(2), 137-144.

[6] Ismail, Y.N., Chorul, S. (2015). Rancang bangun kincir angin sumbu vertikal pembangkit tenaga listrik portable. Seminar Nasional Sains Dan Teknologi Terapan III, 59-68. 